University of Nebraska - Lincoln

DigitalCommons@University of Nebraska - Lincoln

Publications from USDA-ARS / UNL Faculty

U.S. Department of Agriculture: Agricultural

Research Service, Lincoln, Nebraska

2002

Winter Survival in Switchgrass Populations Bred for High IVDMD

Kenneth P. Vogel

University of Nebraska-Lincoln, kvogel1@unl.edu

A. A. Hopkins

Noble Foundation

K. J. Moore

lowa State University

K. D. Johnson

Purdue University

I. T. Carlson

lowa State University

Follow this and additional works at: https://digitalcommons.unl.edu/usdaarsfacpub

Vogel, Kenneth P.; Hopkins, A. A.; Moore, K. J.; Johnson, K. D.; and Carlson, I. T., "Winter Survival in Switchgrass Populations Bred for High IVDMD" (2002). Publications from USDA-ARS / UNL Faculty. 1934. https://digitalcommons.unl.edu/usdaarsfacpub/1934

This Article is brought to you for free and open access by the U.S. Department of Agriculture: Agricultural Research Service, Lincoln, Nebraska at DigitalCommons@University of Nebraska - Lincoln. It has been accepted for inclusion in Publications from USDA-ARS / UNL Faculty by an authorized administrator of DigitalCommons@University of Nebraska - Lincoln. 


\title{
Winter Survival in Switchgrass Populations Bred for High IVDMD
}

\author{
K. P. Vogel,* A. A. Hopkins, K. J. Moore, K. D. Johnson, and I. T. Carlson
}

\begin{abstract}
In vitro dry matter digestibility (IVDMD) was improved by three cycles $(\mathrm{C})$ of recurrent selection in a switchgrass (Panicum virgatum L.) population but significant winter kill occurred in the Cycle 4 (C4) mass selection nursery. Stand density losses in strains differing in IVDMD also were noted in pastures intensively grazed for $3 \mathrm{yr}$. Two studies were conducted to evaluate the effect of genetic changes in IVDMD on plant survival of switchgrass. Seed was harvested from the original high IVDMD C3 parent clones to produce half-sib family seedlings that were planted into a replicated half-sib progeny evaluation nursery in 1991 at Mead, NE. This nursery was harvested in 1993 and 1995 for biomass yield after plants had headed, forage was analyzed for IVDMD, and plant survival was determined. There were significant differences among the families for biomass yield, IVDMD, and plant survival. Among the half-sib families, the correlations of 1993 and 1995 IVDMD with 1995 survival were not significant nor were the correlations between 1993 and 1995 yields and 1995 stands. In the C3 high IVDMD populations, some families had decreased winter survival but other families had high IVDMD and good survival. Randomly selected plants from pasture trials (PC or pasture clones) of 'Trailblazer' and 'Pathfinder' were polycrossed and the resulting bulk populations were evaluated with parent populations in replicated sward trials at three locations along with the High IVDMD C3 population and its derived winter survival (WS) population produced by harvesting bulk seed from surviving plants in the $\mathrm{C} 4$ selection nursery. Differences among populations for stand were not detected in the sward trials, likely because survival and IVDMD have low correlations within populations. It should be feasible to continue to breed for high IVDMD in switchgrass but survival will need to be an additional selection criterion.
\end{abstract}

$\mathrm{S}^{\mathrm{w}}$ ITCHGRASS is one of the principal species on which breeding and genetics research has been conducted to modify genetically herbage for biomass quality traits. Breeding work to improve the IVDMD of switchgrass has been conducted by coauthor Vogel and colleagues for over $20 \mathrm{yr}$ and a series of experiments have been conducted evaluating the breeding progress and associated changes in switchgrass biomass composition (Anderson et al., 1988; Gabrielsen et al., 1990; Hopkins et al., 1993; Vogel et al., 1981, 1984). This research has lead to the release of two switchgrass cultivars, Trailblazer and Shawnee, with improved IVDMD (Vogel et al., 1991, 1996).

Breeding for high IVDMD in switchgrass started in

K.P. Vogel, USDA-ARS, 344 Keim Hall, P.O. Box 830937, Univ. of Nebraska, Lincoln, NE 68583-0937; A.A. Hopkins, Noble Foundation, P.O. Box 2180, Ardmore, OK 73402; K.J. Moore and I.T. Carlson, Dep. of Agronomy, Iowa State Univ., Ames, IA 50011; K.D. Johnson, Dep. of Agronomy, Purdue Univ., West Lafayette, IN 47907-1150, Dep. of Agronomy, Iowa State Univ., Ames, IA 50011 respectively. The research was supported in part by the U.S. Dep. of Energy's Biomass Fuels program via the Oak Ridge National Laboratory Contract no. DE-A105-900R21954. Journal Series no.13444, Nebraska Agric. Exp. Stn. Received 8 Aug. 2001. *Corresponding author (kpv@unlserve. unl.edu).

Published in Crop Sci. 42:1857-1862 (2002). an experiment in which a switchgrass population $(\mathrm{EY} \times$ $\mathrm{FF}$ ) was divergently selected for IVDMD using a modified form of Restricted Recurrent Phenotypic Selection (RRPS) procedures (Vogel et al., 1981). The base population was developed from the 'ey' and 'ff' strains that were developed by L.C. Newell (Newell and Moline, 1978) and originated from collections made in southeastern Nebraska and northeastern Kansas, USA. Two additional cycles of selection for high IVDMD were completed (Hopkins et al., 1993) (Fig. 1) and the sward evaluation trials demonstrated that IVDMD was improved by each breeding cycle. Additional research demonstrated that the improved IVDMD was stable over Midwest environments (Hopkins et al., 1995)

In 1986, a Cycle $4 \mathrm{EY} \times \mathrm{FF}$ High IVDMD RRPS selection nursery was established at Mead, NE, with transplanted seedlings. By the end of the growing season, the plants were well established and had flowered. However, by early summer of 1987, it was obvious that most of the 1196 plants in the nursery had been killed by winter. Only about 100 plants remained alive. In addition to the stand loss in the $\mathrm{C} 4$ selection nursery, apparent stand loss had occurred in switchgrass pastures that had been intensively grazed for $3 \mathrm{yr}$ (Anderson et al., 1988). These pastures, which contained Pathfinder, Trailblazer $(\mathrm{EY} \times \mathrm{FF}$ High IVDMD C1) and the C(-1) Low IVDMD strains, had been established in 1981. At the initiation of grazing in 1982, the switchgrass plants in these pastures were in seeded rows that had virtually no gaps. Because of the dense and uniform stands, no stand counts were taken at that time. Although the stands were still acceptable, it was apparent in the spring of 1985 that stand thinning had occurred. The stands in the pastures consisted of individual switchgrass plants that were about $15 \mathrm{~cm}$ in diameter and which were spatially separated from other plants. Although stand densities were reduced, the remaining stands were similar to expected plant densities for reseeded prairie (Cornelius, 1944). We were concerned that genotypes with high IVDMD may have had lower survival percentages than genotypes with lower IVDMD.

Several studies have subsequently been conducted to evaluate the effect of breeding for high IVDMD on plant yield and survival of switchgrass. A multilocation, multispecies trial was conducted in which space-planted populations of switchgrass, smooth bromegrass (Bromus inermis Leyss), orchardgrass (Dactylic glomerata L.), and alfalfa (Medicago sativa L.) differing in IVDMD or lignin concentration were evaluated for survival and productivity at three Midwest locations for several years (Casler et al., 2002). When evaluated as space-transplanted populations, winter survival of the switchgrass

Abbreviations: IVDMD, in vitro dry matter digestibility; WS, winter survivors; PC, pasture clones. 


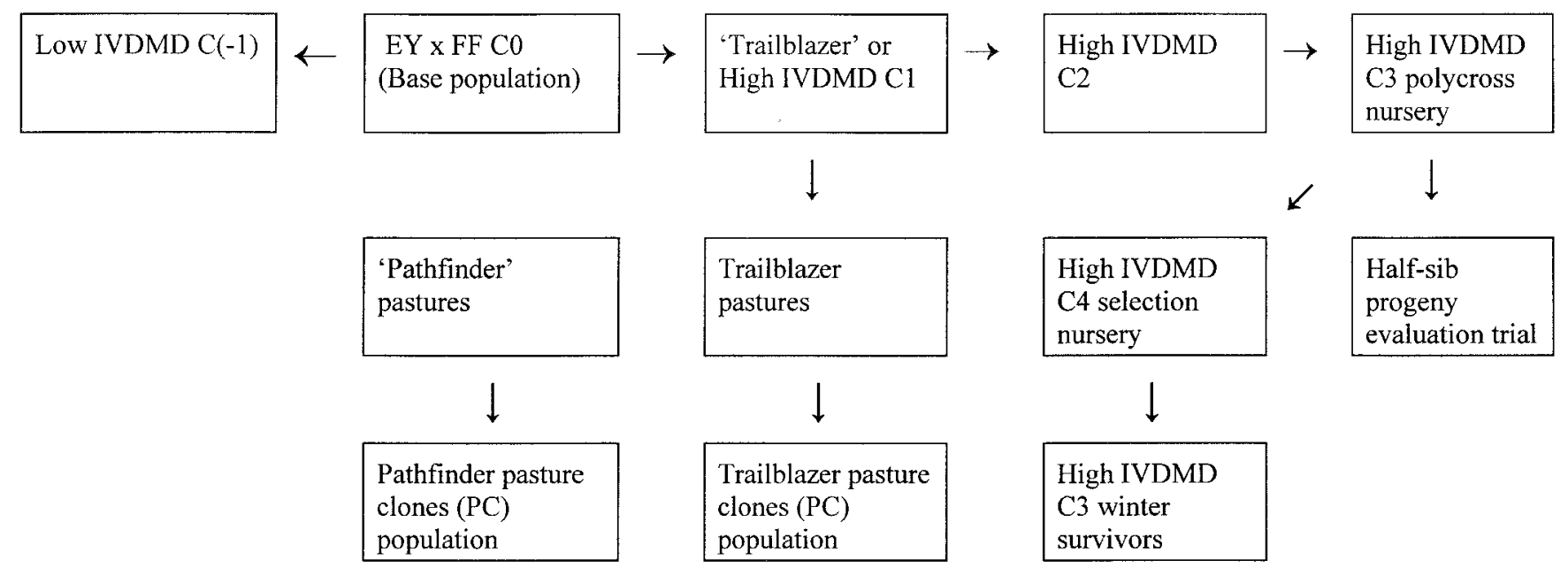

Fig. 1. Development of switchgrass populations and families used to evaluate effect of selection for IVDMD on winter survival. "Cx" indicates the cycle of selection; $\mathrm{C} 0$ is the base population, positive " $\mathrm{C}$ " numbers indicate a generation of selection was practiced for high IVDMD while a negative " $C$ " number indicates that selection was for low IVDMD. Arrows designate a generation.

populations was negatively correlated to cycles of selection for increased IVDMD. In this report, we describe two additional studies. We evaluated the genetic variation for winter survival in the High IVDMD C3 population on a within-population basis using half-sib families and determined the correlation between survival and IVDMD in a multiyear space-transplanted field experiment. In another study, sward trials were used to determine if genetic shifts in population IVDMD means had occurred because of differential survival of switchgrass plants in pastures and the $\mathrm{C} 4$ selection nursery in which the substantial winter kill had occurred.

\section{MATERIALS AND METHODS}

\section{Study 1. Genetic Variation in EY $\times$ FF High IVDMD C3 Population for IVDMD and Survival}

Seed was harvested from each clone (two replicates) of the 48 genotypes of the EY $\times$ FF High IVDMD C3 polycross nursery and bulked by genotype to form 48 half-sib families. Greenhouse grown seedlings were transplanted into a field evaluation nursery on 29 May 1991. The seedlings were planted in Cone-tainer seedling tubes (Ray Leach Supercells, Stuewe and Sons, Inc, Corvallis, OR) in January 1991 and thinned to one per seedling tube after emergence. The experimental design was a replicates-in-block design with three replicates and five blocks. The 48 half-sib families were assigned at random to five sets or blocks. Four blocks contained 10 half-sib families and three check strains. The fifth block had eight half-sib families and the check strains. The check strains were the $\mathrm{EY} \times \mathrm{FF}$ Low IVDMD C(-1), High IVDMD C1 or Trailblazer, and a EY $\times$ FF High IVDMD C3 bulk population produced by bulking an equal amount of seed from each polycrossed genotype (Fig. 1). Plots were single rows of eight plants spaced $1.1 \mathrm{~m}$ apart within and between rows. The nursery was fertilized annually in the spring with a single application of $110 \mathrm{~kg} \mathrm{ha}^{-1} \mathrm{~N}$. Weeds were controlled by a combination of herbicides, roto-tilling, and hand weeding. The nursery was harvested at a cutting height of $10 \mathrm{~cm}$ on 4 Aug. 1993 and on 8 Aug. 1995 for biomass yield on a plot basis after plants had headed. The plots were visually scored for maturity on the harvest date by means of the index of Moore et al. (1993).
Variation in maturity was minimal and is not reported. The nursery was harvested in 1992 and 1994 but yields were not recorded. Forage samples for IVDMD analysis were collected on a plot basis at the time of harvest. The number of surviving plants was determined at the time of harvest. A plant was scored as surviving if it had any green tissue at the time of harvest. Forage yield was converted to yield per plant by dividing plot yield by the number of surviving plants at that harvest.

\section{Study 2. Sward evaluation High IVDMD C3 Winter Survivor (WS) and Pathfinder and Trailblazer Pasture Clone (PC) populations}

In the spring of 1985, 30 plants were dug at random from each of the four replicate Trailblazer (C1) and Pathfinder pastures described by Anderson et al. (1988). The 120 genotypes were transplanted into Trailblazer Pasture Clone (PC) or Pathfinder Pasture Clone (PC) isolated crossing blocks located near Mead, NE. Seed was harvested from individual plants in these nurseries in 1987 and an equal amount of seed was bulked from each plant or clone to form the Trailblazer PC and Pathfinder PC populations (Fig. 1). Seed was harvested from all the surviving plants in the EY $\times$ FF High IVDMD C4 selection nursery in which winter kill had occurred and bulked to produce a High IVDMD C3 WS (winter survivor) population (Fig. 1). These strains, as well as the cultivars or populations from which they were derived, were included in the multistate trials summarized by Hopkins et al. (1995). The results of the specific comparisons between base and survivor populations for stands, IVDMD, and yield were not described or discussed by Hopkins et al. (1995). In brief, the strains were planted in small plot sward trials near Mead, NE, Ames, IA, and West Lafayette, IN, in 1990 and harvested during 1991 and 1992 (Hopkins et al., 1995). They were harvested for forage or biomass yield at heading and regrowth was harvested in the fall. They also were sampled for IVDMD at a vegetative or preboot growth stage. Yields were reported on a dry weight basis. Stand percentages were determined after harvest by means of a frequency grid (Hopkins et al., 1995; Vogel and Masters, 2001). 
Table 1. Analysis of variance for herbage yield, IVDMD, and plant survival of $48 \mathrm{EY} \times$ FF High IVDMD C3 switchgrass half-sib families and 3 check strains grown at Mead, NE, 1991 to 1995.

\begin{tabular}{|c|c|c|c|c|c|c|c|}
\hline \multirow[b]{3}{*}{ Source } & \multirow[b]{3}{*}{ df } & \multicolumn{6}{|c|}{ Mean squares } \\
\hline & & \multicolumn{2}{|c|}{ Survival } & \multicolumn{2}{|c|}{ Herbage yield } & \multicolumn{2}{|c|}{ IVDMD } \\
\hline & & 1993 & 1995 & 1993 & 1995 & 1993 & 1995 \\
\hline & & 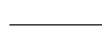 & 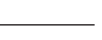 & 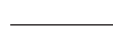 & $\longrightarrow$ & 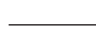 & - \\
\hline Replicate & 2 & $12.09 * *$ & $57.5^{* *}$ & 0.0159 & 0.3052** & $2068 * *$ & $6034 * *$ \\
\hline Entry & 50 & $2.01 * *$ & $7.82 * *$ & $0.0474 * *$ & $0.0954 * *$ & $1092 * *$ & $1627 * *$ \\
\hline Error & $131 \dagger$ & 0.99 & 3.64 & 0.0140 & 0.061 & 411 & 939 \\
\hline
\end{tabular}

* Indicates significance at $\boldsymbol{P}=\mathbf{0 . 0 5}$.

*** Indicates significance at $\boldsymbol{P}=\mathbf{0 . 0 1}$.

$\uparrow$ Degrees of freedom for error for traits measured ranged from 128 to 133 due to missing observations or unharvestable yields.

\section{Laboratory Procedures for Forage Quality Analysis for Study 1 and Study 2}

Samples in both studies were collected by cutting tillers at a $10-\mathrm{cm}$ height with hand sickles at the vegetative stage or before harvest or by taking subsamples from the plot harvester after the plot was harvested. Four or more subsamples were randomly collected and bulked for each plot. Approximately 200 to $300 \mathrm{~g}$ of sample (wet weight) was collected from each plot. The sampling procedure that was used varied with location and year, but the same sampling procedure was used for a single harvest. Samples were dried at $50^{\circ} \mathrm{C}\left(60^{\circ} \mathrm{C}\right.$ at West Lafayette) and dry weights were used to adjust yields to a dry weight basis. Samples were ground through a Wiley type mill to pass a 1-mm screen and again through a 1-mm screen of a cyclone mill. Sample NIRS spectra were collected from all dried and ground samples with a Model 6500 near infrared reflectance spectrometer (NIRS Systems, Silver Spring, MD) for Study 1 and a Technicon Infralyzer 500 (Bran \& Luebbe Analyzing Technologies, Buffalo Grove, IL) for Study 2. Samples representative of the spectra (Study 1) and the experimental variables, i.e., locations, years, replicates, and entries (Study 2) were selected for laboratory determination of IVDMD. The laboratory procedures used for IVDMD are described by Hopkins et al. (1995) and were used for both studies. The laboratory values were then used to develop NIRS prediction equations. The prediction calibrations for Study 2 are listed by Hopkins et al. (1995). The calibration statistics for Study 1 were $R^{2}=0.85, \mathrm{SEC}=19.6 \mathrm{~g} \mathrm{~kg}^{-1}, \mathrm{SECV}=2.38 \mathrm{~g} \mathrm{~kg}^{-1}$.

\section{Statistical Analyses}

In the initial analysis of variance for Study 1, block effects for the replicates-in-block design were not significant for any of the traits evaluated except for 1993 dry matter yield at the 0.05 level of probability. Consequently, the data was reanalyzed as a simple randomized block design to facilitate comparisons between treatment means. Pairwise comparisons were made between parent and derived populations in Study 2 by Fisher LSD values.

\section{RESULTS}

\section{Study 1. Genetic Variation in EY $\times$ FF High IVDMD C3 Population for IVDMD and Survival}

There were significant differences among the families for forage biomass yield, IVDMD, and plant survival among the half-sib families and the check populations for 1993 and 1995 (Table 1 and Fig. 2). Survival percentages were lower in 1995 than in 1993 for both halfsib families and check populations (Table 2). Average monthly temperatures for January, Febreaury, November, and December for the winter of 1991-1992 were warmer than for the subsequent years (Fig. 3) and winter kill did not become apparent until the spring of 1993. In 1993, the EY $\times$ FF High IVDMD C3 bulk population

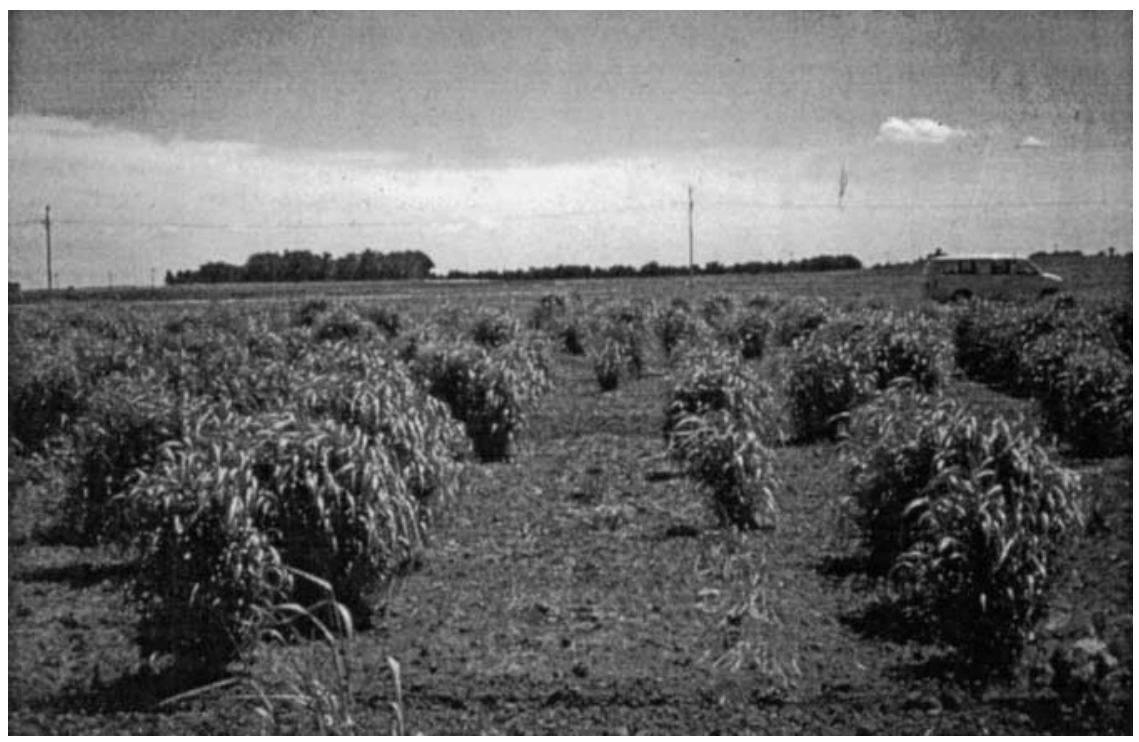

Fig. 2. EY $\times$ FF High IVDMD C4 switchgrass half-sib family space-transplanted selection nursery at Mead, NE, in 1995 showing differential survival among and within families. 
Table 2. Mean and range values for $48 \mathrm{EY} \times \mathrm{FF}$ High IVDMD C3 switchgrass half-sib families and EY $\times \mathrm{FF}$ check strains grown at Mead, NE from 1991 through 1995 for survival, herbage yield, and IVDMD.

\begin{tabular}{|c|c|c|c|c|c|c|}
\hline \multirow[b]{2}{*}{ Entries } & \multicolumn{2}{|c|}{ Survival } & \multicolumn{2}{|c|}{ Herbage yield } & \multicolumn{2}{|c|}{ IVDMD } \\
\hline & 1993 & 1995 & 1993 & 1995 & 1993 & 1995 \\
\hline & \multicolumn{2}{|c|}{$\%$} & \multicolumn{2}{|c|}{$\longrightarrow$ kg plant ${ }^{-1}$} & \multicolumn{2}{|c|}{$-\mathbf{g ~ k g}^{-1}$} \\
\hline Low IVDMD C $(-1) \dagger$ & 97 & 68 & 0.71 & 0.73 & 538 & 490 \\
\hline High IVDMD C1 $\uparrow$ (Trailblazer) & 98 & 76 & 0.73 & 0.66 & 546 & 495 \\
\hline High IVDMD C3 bulk $\dagger$ & 96 & 54 & 0.60 & 0.44 & 572 & 524 \\
\hline \multicolumn{7}{|l|}{$\mathrm{C3}$ half-sib progeny $\dagger$} \\
\hline Mean & 93 & 49 & 0.59 & 0.49 & 569 & 517 \\
\hline Minimum & 71 & 19 & 0.36 & 0.18 & 533 & 466 \\
\hline Maximum & 100 & 88 & 0.82 & 1.00 & 613 & 576 \\
\hline LSD 0.05 & 2 & 3 & 0.19 & 0.40 & 33 & 50 \\
\hline \multicolumn{7}{|l|}{ Specific families } \\
\hline 519 & 92 & 19 & 0.65 & 0.20 & 585 & 466 \\
\hline 511 & 100 & 88 & 0.65 & 0.54 & 555 & 521 \\
\hline 829 & 71 & 50 & 0.48 & 0.18 & 566 & 558 \\
\hline 1127 & 100 & 38 & 0.80 & 1.00 & 566 & 486 \\
\hline 1135 & 92 & 21 & 0.40 & 0.36 & 558 & 576 \\
\hline 212 & 96 & 75 & 0.67 & 0.40 & 562 & 513 \\
\hline
\end{tabular}

$\dagger$ All populations are derived by selection from the $\mathrm{EY} \times \mathrm{FF}$ base population.

had similar survival to both Trailblazer and the Low IVDMD C(-1) strains but by 1995 had significantly lower survival percentages. Some families in the High IVDMD C3 population, however, had survival percentages equivalent to survival percentages of Trailblazer and Low IVDMD C(-1). Some families had survival percentages as low as $19 \%$. Nonsurviving plants failed to resume growth in the spring and plant death is likely associated with winter kill.

Herbage or biomass yield of the EY $\times$ FF High IVDMD C3 bulk population was lower than the yield of Trailblazer or Low IVDMD C(-1) in both 1993 and 1995 but the differences were not significant (Table 2). In both years, however, some families had significantly lower yields than Trailblazer and Low IVDMD C(-1) but some families had similar yields. Experimental errors were high in 1995 because although some plants had greatly reduced vigor and yield, they were scored as survivors.

The EY $\times$ FF High IVDMD C3 bulk population had significantly higher IVDMD than the Low IVDMD C(-1) population in 1993 and it was higher in IVDMD than Trailblazer at approximately the 0.10 level of probability. The same relative differences among these populations existed in 1995 but the differences were not significant because of the larger experimental error associated with differential survival among plants within and among plots. The mean of the half-sib progenies, as expected, was about the same as the mean of the EY $\times$ FF High IVDMD C3 bulk population for IVDMD. Some families had IVDMD means that were significantly higher than the IVDMD of both Trailblazer and the EY $\times$ FF High IVDMD C3 bulk population.

Neither the Pearson nor Spearman correlations between 1993 and 1995 survival percentages were significant (Table 3) among the half-sib progenies. From only field observations and data, it would not have been possible to predict before 1995 which families would have had the best survival percentages $4 \mathrm{yr}$ after establishment. Survival percentage in 1993 was positively correlated to 1993 yield, as expected, but was not correlated to 1995 yield (Pearson correlation). Survival percentage

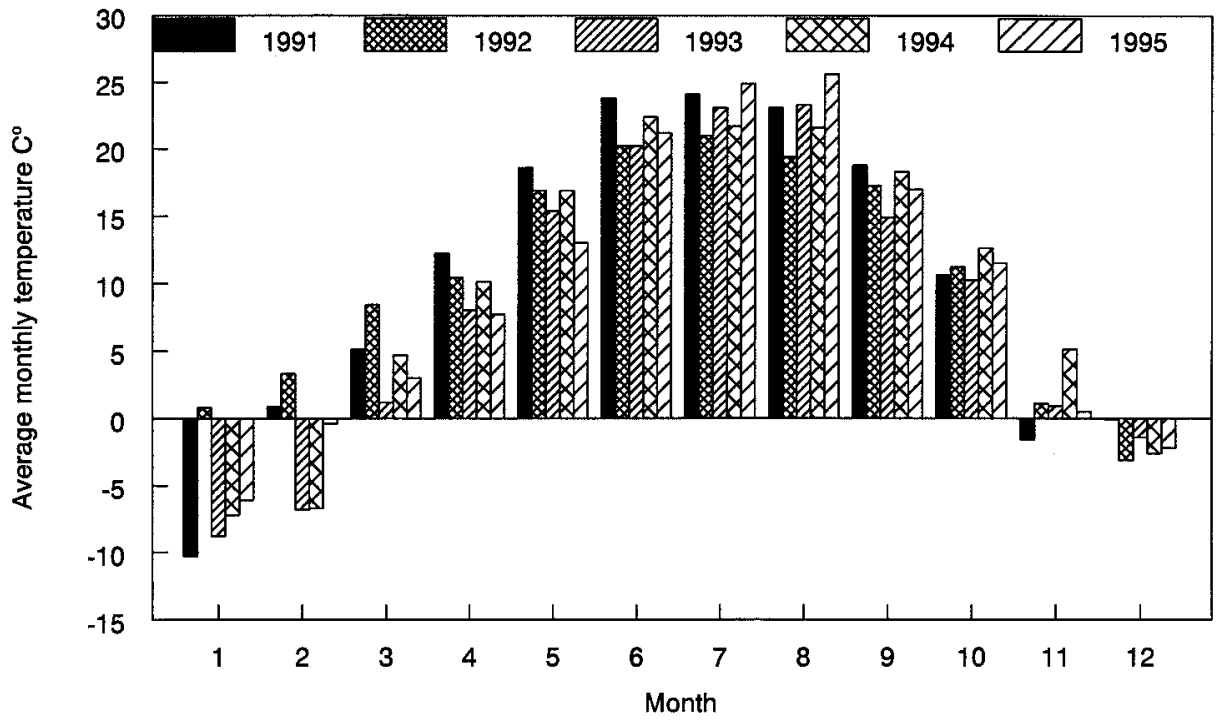

Fig. 3. Average monthly temperatures for Mead, NE, for the period 1991 through 1995. 
Table 3. Pearson (above diagonal) and Spearman (below diagonal) correlations among EY $\times$ FF High IVDMD C3 half-sib families for survival, herbage yield, and IVDMD in 1993 and 1995.

\begin{tabular}{|c|c|c|c|c|c|c|}
\hline \multirow[b]{2}{*}{ Trait } & \multicolumn{2}{|c|}{ Survival \% } & \multicolumn{2}{|c|}{ Herbage yield $\left(\mathrm{kg} \mathrm{plant}^{-1}\right)$} & \multicolumn{2}{|c|}{ IVDMD ( $\left.\mathrm{g} \mathrm{kg}^{-1}\right)$} \\
\hline & 1993 & 1995 & 1993 & 1995 & 1993 & 1995 \\
\hline Survival 1993 & & 0.14 & $0.49 *$ & 0.24 & 0.09 & $-0.34 *$ \\
\hline Survival 1995 & 0.15 & & 0.22 & 0.08 & 0.21 & -0.11 \\
\hline Yield 1993 & $0.47 * *$ & 0.24 & & 0.00 & -0.01 & $-0.30 *$ \\
\hline Yield 1995 & $0.28 *$ & 0.09 & 0.02 & & $-\mathbf{0 . 0 3}$ & -0.24 \\
\hline IVDMD 1993 & 0.08 & 0.26 & 0.00 & -0.02 & & -0.19 \\
\hline IVDMD 1995 & -0.21 & -0.08 & $-0.31^{*}$ & -0.18 & -0.17 & \\
\hline
\end{tabular}

* Indicates significance at $\boldsymbol{P}=\mathbf{0 . 0 5}$

** Indicates significance at $\boldsymbol{P}=\mathbf{0 . 0 1}$.

in 1995 was not correlated to either 1993 or 1995 yields. Survival percentage and IVDMD were not correlated except 1993 survival had a low negative Pearson correlation with 1995 IVDMD.

The 48 half-sib families were assigned to 12 frequency classes based on their 1995 IVDMD. Except for the frequency class with the highest IVDMD, the 1995 mean survival percentage for these frequency classes were all within a 13 percentage point range (Table 4). Survival percentages in 1993 were similar among 1995 IVDMD frequency classes except for the frequency classes with midpoints $555 \mathrm{~g} \mathrm{~kg}^{-1}$ or higher (Table 4). The same relationships existed for 1993 and 1995 yield and 1993 IVDMD. Five half-sib families had 1995 IVDMD values numerically lower than Trailblazer in 1995 (Tables 2 and 4). Ten families had numerically higher means than the EY $\times$ FF High IVDMD C3 bulk population and seven families had significantly higher IVDMD than Trailblazer (Tables 2 and 4).

\section{Study 2. Sward Evaluation High IVDMD C3 Winter Survivor (WS) and Pathfinder and Trailblazer Pasture Clone (PC) Populations}

There were no significant differences between the $\mathrm{EY} \times$ FF High IVDMD C3 and EY $\times$ FF High IVDMD C3 WS strains for any of the traits evaluated in 1991 and 1992 including IVDMD determined at both vegetative and heading stages of maturity, and forage or biomass yield at any of the three sward evaluation locations

Table 4. Means for 1995 IVDMD frequency classes $\left(\mathrm{g} \mathrm{kg}^{-1}\right)$ for 48 EY $\times$ FF C3 switchgrass half-sib families grown at Mead, NE, from 1991 through 1995.

\begin{tabular}{|c|c|c|c|c|c|c|}
\hline $\begin{array}{l}\text { Class mid-point } \\
1995 \text { IVDMD }\end{array}$ & $N$ & $\begin{array}{c}\text { Survival } \\
1993\end{array}$ & $\begin{array}{c}\text { Survival } \\
1995\end{array}$ & $\begin{array}{c}\text { IVDMD } \\
1993\end{array}$ & $\begin{array}{l}\text { Yield } \\
1993 \\
\end{array}$ & $\begin{array}{l}\text { Yield } \\
1995 \\
\end{array}$ \\
\hline \multicolumn{2}{|l|}{$\mathrm{g} \mathrm{kg}^{-1}$} & \multicolumn{2}{|c|}{$\%$} & $\mathrm{~g} \mathrm{~kg}^{-1}$ & \multicolumn{2}{|c|}{- kg plant ${ }^{-1}$} \\
\hline $\begin{array}{l}465 \\
475\end{array}$ & $\begin{array}{l}2 \\
0\end{array}$ & 88 & 41 & 579 & 0.61 & 0.37 \\
\hline 485 & 3 & 100 & 47 & 570 & 0.65 & 0.84 \\
\hline 495 & 6 & 96 & 54 & 573 & 0.69 & 0.47 \\
\hline 505 & 6 & 92 & 45 & 572 & 0.52 & 0.49 \\
\hline 515 & 8 & 97 & 49 & 560 & 0.56 & 0.45 \\
\hline 525 & 11 & 96 & 54 & 574 & 0.62 & 0.51 \\
\hline 535 & 5 & 89 & 43 & 564 & 0.51 & 0.60 \\
\hline 545 & 3 & 95 & 47 & 572 & 0.61 & 0.44 \\
\hline 555 & 3 & 75 & 53 & 563 & 0.54 & 0.28 \\
\hline 565 & 0 & & & & & \\
\hline 575 & 1 & 71 & 21 & 558 & 0.40 & 0.36 \\
\hline \multicolumn{7}{|l|}{ Half-sib family } \\
\hline Mean LSD 0.05 & & 3 & 2 & 33 & 0.19 & 0.40 \\
\hline
\end{tabular}

(Table 5). Significant stand loss did not occur in any of these nurseries, but since the plots were solid seeded, loss of plants could have been compensated by tillering of adjacent surviving plants. There also were no significant differences between the Trailblazer or Pathfinder Pasture Clone (PC) populations and their base populations at any of the three locations for IVDMD, herbage yield, or stands (Table 5). The EY $\times$ FF High IVDMD $\mathrm{C} 3$ and EY $\times$ FF High IVDMD C3 WS populations were higher in IVDMD than Trailblazer at the three locations and also were lower in forage yield.

\section{DISCUSSION}

Three cycles of breeding for increased herbage IVDMD in the $\mathrm{EY} \times \mathrm{FF}$ switchgrass population did improve IVDMD at the population level in both spaceplanted and sward trials but it also reduced plant biomass yield and plant survival in the spaced-planted trials. The EY $\times$ FF C-1, C0, C1, C2, and C3 High IVDMD populations were evaluated by Casler et al. (2002) in space-planted, multisite trials and in their tests, plant survival percentages and biomass yield of these switchgrass populations also decreased significantly with each cycle of selection for high IVDMD as indicated by regression analyses. The results of this study demonstrate that the decrease in survival in the C3 High IVDMD population can be attributed to differential survival among families within the population. Some families had very low survival percentages while others had survival percentages equivalent to Trailblazer. Among families, survival percentage and IVDMD were not correlated, so it should be feasible to continue to breed for high IVDMD in this population if selection is based on multiyear family evaluation trials in which plant survival is monitored and is a selection criterion.

Difference in survival was probably not detected in the sward plots because of tillering of surviving plants. Since survival percentage and IVDMD among families within the EY $\times$ FF High IVDMD C3 population was not correlated, the surviving plants in swards probably had mean IVDMD and forage yield values that were similar to the mean of the original population. A similar situation likely exists for the pasture clones and their base populations. Although plant density did decrease in the pastures, the surviving plants had similar yield and IVDMD potential as the base populations, as demonstrated by the performance of their progeny in the 
Table 5. Means comparisons for biomass yield, IVDMD, crude protein (CP), and stand percentage of Pathfinder and Trailblazer, populations produced from plants dug from pastures of these strains that were grazed for three summers (pasture clones or PC), EY $\times$ FF High IVDMD C3 (High IVDMD C3), and EY $\times$ FF High IVDMD winter survivor (High IVDMD C3 WS) populations when evaluated in swards at three midwestern locations.

\begin{tabular}{|c|c|c|c|c|c|}
\hline \multirow[b]{2}{*}{$\underline{\text { Strain }}$} & \multirow[b]{2}{*}{ Location } & \multirow[b]{2}{*}{ Yield } & \multicolumn{2}{|c|}{ IVDMD } & \multirow[b]{2}{*}{ Stand } \\
\hline & & & Vegetative stage & Mature stage & \\
\hline & & $\operatorname{kg~ha}^{-1}$ & $\mathrm{~g} \mathrm{~kg}^{-1}$ & $\mathrm{~g} \mathrm{~kg}^{-1}$ & $\%$ \\
\hline $\begin{array}{l}\text { Pathfinder } \\
\text { Pathfinder PC } \\
\text { Trailblazer } \\
\text { Trailblazer PC } \\
\text { High IVDMD C3 } \\
\text { High IVDMD C3 WS } \\
\text { SE }\end{array}$ & Mead & $\begin{array}{l}12320 \\
12790 \mathrm{~ns} \\
12330 \\
12900 \mathrm{~ns} \\
10860 \\
11950 \mathrm{~ns} \\
\quad 720\end{array}$ & $\begin{array}{l}659 \\
656 n s \\
651 \\
664 n s \\
697 \\
687 n s \\
\quad 8\end{array}$ & $\begin{array}{l}450 \\
429 \mathrm{~ns} \\
444 \\
477 \mathrm{~ns} \\
491 \\
492 \mathrm{~ns} \\
\quad 11\end{array}$ & $\begin{array}{l}92 \\
90 \mathrm{~ns} \\
94 \\
89 \mathrm{~ns} \\
90 \\
87 \mathrm{~ns} \\
2\end{array}$ \\
\hline $\begin{array}{l}\text { Pathfinder } \\
\text { Pathfinder PC } \\
\text { Trailblazer } \\
\text { Trailblazer PC } \\
\text { High IVDMD C3 } \\
\text { High IVDMD C3 WS } \\
\text { SE }\end{array}$ & Ames & $\begin{array}{l}10510 \\
10880 \mathrm{~ns} \\
9840 \\
9340 \mathrm{~ns} \\
8460 \\
9340 \mathrm{~ns} \\
\quad 850\end{array}$ & $\begin{array}{l}588 \\
592 n s \\
623 \\
604 n s \\
641 \\
633 n s \\
10\end{array}$ & $\begin{array}{l}424 \\
429 \mathrm{~ns} \\
431 \\
448 \mathrm{~ns} \\
491 \\
454 \mathrm{~ns} \\
\quad 15\end{array}$ & $\begin{array}{l}100 \\
99 \mathrm{~ns} \\
99 \\
98 \mathrm{~ns} \\
98 \\
99 \mathrm{~ns} \\
1\end{array}$ \\
\hline $\begin{array}{l}\text { Pathfinder } \\
\text { Pathfinder PC } \\
\text { Trailblazer } \\
\text { Trailblazer PC } \\
\text { High IVDMD C3 } \\
\text { High IVDMD C3 WS } \\
\text { SE }\end{array}$ & West Lafayette & $\begin{array}{l}12390 \\
11450 \mathrm{~ns} \\
13390 \\
11660 \mathrm{~ns} \\
10130 \\
10590 \mathrm{~ns} \\
\quad 850\end{array}$ & $\begin{array}{l}\mathbf{5 6 0} \\
\mathbf{5 4 8 n s} \\
\mathbf{5 6 9} \\
\mathbf{5 6 9 n s} \\
\mathbf{5 9 2} \\
\mathbf{5 8 7 n s} \\
\quad \mathbf{8}\end{array}$ & $\begin{array}{l}399 \\
404 n s \\
412 \\
425 n s \\
438 \\
438 n s \\
\quad 5\end{array}$ & $\begin{array}{l}100 \\
100 \mathrm{~ns} \\
99 \\
99 \mathrm{~ns} \\
99 \\
99 \mathrm{~ns} \\
2\end{array}$ \\
\hline
\end{tabular}

ns Indicates parent and derived population means are not significantly different at the 0.05 level of probability for pairwise comparisons.

multisite sward trials. There may have been shifts in the derived pasture populations (PC populations), but they were not detected for the traits measured in the sward trials. In the USDA-ARS switchgrass breeding program at Nebraska, plant survival has not developed as a problem in populations in which selection was based on both plant yield and IVDMD. Concurrent selection for yield may be an indirect method of selecting for survival when breeding for increased IVDMD as suggested by the positive but not always significant correlations between yield and survival.

\section{REFERENCES}

Anderson, B., J.K. Ward, K.P. Vogel, M.G. Ward, H.J. Gorz, and F.A. Haskins. 1988. Forage quality and performance of yearlings grazing switchgrass strains selected for differing digestibility. J. Anim. Sci. 66:2239-2244.

Casler, M.D., D.R. Buxton, and K.P. Vogel. 2002. Genetic modification of lignin concentration affects winter survival of perennial herbaceous plants. Theor. Appl. Genet. 104:127-131.

Cornelius, D.R. 1944. Revegetation in the tallgrass prairie region. J. Am. Soc. Agron. 36:393-400.
Gabrielsen, B.C., K.P. Vogel, B.E. Anderson, and J.K. Ward. 1990. Alkali-labile lignin phenolics and forage quality in three switchgrass strains selected for differing digestibility. Crop Sci. 30:1313-1320.

Hopkins, A.A., K.P. Vogel, and K.J. Moore. 1993. Predicted and realized gains from selection for in vitro dry matter digestibility and forage yield in switchgrass. Crop Sci. 33:253-258.

Hopkins, A.A., K.P. Vogel, K.J. Moore, K.D. Johnson, and I.T. Carlson. 1995. Genotype effects and genotype by environment interactions for traits of elite switchgrass populations. Crop Sci. 35:125132.

Newell, L.C., and W.J. Moline. 1978. Forage quality evaluation of twelve grasses in relation to season of grazing. Nebr. Res. Bull. 283.

Moore, K.J., L.E. Moser, K.P. Vogel, S.S. Waller, B.E. Johnson, and J.F. Pedersen. 1991. Describing and quantifying growth stages of perennial forage grasses. Agron. J. 83:1073-1077.

Vogel, K.P., R. Britton, H.J. Gorz, and F.A. Haskins. 1984. In vitro and in vivo analyses of hays of switchgrass strains selected for high and low IVDMD. Crop Sci. 24:977-980.

Vogel, K.P., H.J. Gorz, and F.A. Haskins. 1981. Divergent selection for in vitro dry matter digestibility in switchgrass. Crop Sci. 21:39-41.

Vogel, K.P., F.A. Haskins, H.J. Gorz, B.A. Anderson, and J.K. Ward. 1991. Registration of 'Trailblazer' switchgrass. Crop Sci. 31:1388.

Vogel, K.P., A.A. Hopkins, K.J. Moore, K.D. Johnson, and I.T. Carlson. 1996. Registration of 'Shawnee' switchgrass. Crop Sci. 36:1713.

Vogel, K.P., and R.A. Masters. 2001. Frequency Grid-A simple tool for measuring grassland establishment. J. Range Manage. 54:653655 . 